\title{
Carbon Absorption Control Model of Oil Palm Plantation
}

(Model Kawalan Penyerapan Karbon Ladang Kelapa Sawit)

\author{
NORYANTI NASIR*, MOHD ISMAIL ABD AZIZ \& AKBAR BANITALEBI
}

\begin{abstract}
Among the largest and growing oil palm industries, Malaysia plays an important role in the world's oil market. The contribution of the palm plantation in absorbing carbon from the atmosphere is also considerable thought, it is rarely studied. The role of the plantation in balancing carbon dioxide is significant. However, the ability of palm tree in absorbing carbon may vary within the lifespan of the plant. Therefore, managing the plantation to reach the maximum carbon dioxide absorption along with maximum oil production is challenging. This study is aimed at analyzing the carbon absorption level of the palm oil plantation. A mathematical model is proposed by considering the characteristics of palm oil trees in absorbing carbon and producing oil. It is assumed that the rate of felling can be controlled, and a system of ordinary differential equations is developed to describe the behaviour of the plantation in terms of biomass and growth rate dynamics. The resulting parameter estimation problem is solved which leads to an optimal control problem. The objective of this problem was to maximize the oil production as well as carbon absorption. Numerical simulation is illustrated to highlight the application of the proposed model.
\end{abstract}

Keywords: Carbon absorption; optimal control model; palm oil biomass

\section{ABSTRAK}

Malaysia antara negara industri kelapa sawit terbesar dan masih berkembang yang memainkan peranan penting dalam pasaran minyak dunia. Sumbangan perladangan kelapa sawit dalam menyerap karbon dari atmosfera amat mustahak, namun jarang dikaji. Walau bagaimanapun, keupayaan pokok sawit dalam menyerap karbon mungkin berbeza mengikut jangka hayat tumbuhan. Oleh itu menguruskan ladang untuk mencapai penyerapan karbon dioksida yang maksimum berserta dengan pengeluaran minyak maksimum adalah mencabar. Kajian ini bertujuan untuk menganalisis tahap penyerapan karbon daripada ladang kelapa sawit. Model matematik adalah dicadangkan dengan mengambil kira ciriciri pokok kelapa sawit dalam menyerap karbon dan menghasilkan minyak. Ia diandaikan bahawa kadar penebangan boleh dikawal, sistem persamaan pembezaan biasa (ODE) dibangunkan untuk menerangkan tingkah laku perladangan daripada segi biojisim dan kadar pertumbuhan dinamik. Keputusan daripada parameter anggaran membawa kepada penyelesaian masalah kawalan optimum. Objektif masalah ini adalah untuk memaksimumkan pengeluaran minyak serta penyerapan karbon. Simulasi berangka digambarkan untuk menyerlahkan aplikasi model yang dicadangkan.

Kata kunci: Kelapa sawit biojisim; model kawalan optimum, penyerapan karbon

\section{INTRODUCTION}

Malaysia is among the largest and growing palm oil industry, playing an important role in the world's oil market. Driven by palm oil plantation affecting environmental such as increase deforestation rate and reducing carbon reservations, the government insists on finding win-win solution (Al-Amin et al. 2015). Carbon sequestration potential in oil palm plantation reported significant attention among researchers (Kho \& Jepsen 2015; Kongsager et al. 2013; Pulhina et al. 2014; Sanquetta et al. 2015). Thus, maintaining the carbon absorption in palm oil plantation is crucial for the entire ecosystem and at the same time persistently supplies the oil to the world's market.

Few researchers claimed that the palm tree plantation leads to deforestation due to regular felling and replanting process (Mekhilef et al.2011; Wicke et al. 2011). Contrary, few discussions among studies disagreed, they claimed that expanding plantation growth does not play a big part on carbon sequestration (Germer \& Sauerborn 2008; Patthanaissaranukool et al. 2013). On top of that carbon absorption in plantation is said to be less compared to absorption of virgin forest and other crop plantation (Aholoukpè et al. 2013; Basiron 2007; Kongsager et al. 2013; Pei et al. 2012) yet highest in oil crop plantation (Sharma 2013).

Comprehensive survey on the mathematical modelling and analysis of carbon sequestration has been investigated intensively and published (Assmuth 2015; Backeus et al. 2006; Goetz et al. 2007; Hritonenko et al. 2008; Kongsager et al. 2013; Kula \& Gunalay 2012; Pulhina et al. 2014; Sanquetta et al. 2015; Xabadia \& Goetz 2010). The tradeoffs analysis between carbon sequestration and forest timber production showed level of carbon sequestration 
was governed by the level of felling, thinning and the forest productivity (Backeus et al. 2006; Sohngen \& Mendelsohn 2003; Sohngen et al. 2009).

Studies on quantifying carbon stock from tree biomass has been often urged in oil palm plantation (Aholoukpè et al. 2013; Corley \& Tinker 2003; Kho \& Jepsen 2015; Kongsager et al. 2013; Sanquetta et al. 2015). However, there is little evidence that the amount of carbon released during palm oil felling activity has any long-term negative impact on net sequestration as the biomass stands absorb released carbon in a relatively short time frame (Jones \& O’Hara 2012; Kho \& Jepsen 2015). Whereas felling activity of palm oil tree has different impact on carbon absorption. Assume that the rotation age is rounded to 25 years old. If there are 33 million hectares of palm oil land in Malaysia, then on average 1.32 million hectares will be cut each year (Sohngen et al. 2009).

Previously, carbon stock is estimated using allometric equations, discussed in Corley et al. (1971), Kongsager et al. (2013) and Somarriba et al. (2013). Corley et al. (1971) established allometric equations to predict oil palm frond and trunk biomass without considering felling activity. Based on Corley et al. (1971) and supported by Aholoukpe et al. (2013) and Syahrinuddin (2005), the growth of oil palm tree is reported increases linearly with age up to about 10 years and constant thereafter (Pulhina et al. 2014; Sanquetta et al. 2015; Syahrinudin 2005).

The problem of optimal felling was considered in many literatures (Kato 2008). Gaoue et al. (2016) studied and developed a new felling model incorporates nonlethal and lethal felling. This study added a parameter of average lifespan of plantation to account direct effect of felling through system of ODEs. By following logistic model, Gaoue et al. (2016) investigated how exponential growth rate and lifespan affect optimal felling strategies and result in increases the production of plantation.

An optimal forest carbon storage is normally studied using a classical rotation optimal model, continuous time biomass model and discrete time size structured model (Assmuth 2015). These models showed that subsidized carbon sequestration postpones thinning and increases optimal stand volume along the rotation. Sohngen and Mendelsohn (2003) develop an optimal control model of carbon sequestration and energy abatement to explore the potential role of forests in greenhouse gas mitigation. The result showed that amounts of carbon in forests increases mainly by increasing forestland and lengthening rotations.

Recently, Sanquetta et al. (2015) quantified biomass and carbon stock in oil palm plantation via the Chapman and Richard models. The model was fitted to the total biomass and carbon as a function of age. The results showed that total biomass was highly correlated with age and able to stock a high amount of carbon per unit area. Hritonenko et al. (2008) on the other hand, describes that the amount of carbon sequestered in timber is equal with forest volume multiplied with distribution density. Another optimal carbon sequestration model were produced by Jiao et al. (2011), introduced the concept of relaxation and the box-style ideas with eddy correlation method to estimate quantitatively carbon sequestration of trees. The result showed that this method reduced the error of estimation and effectively increases the estimation efficiency of forest carbon sequestration.

The aim of this study was to develop an optimal control model for maximizing the carbon absorption and oil production via optimal control of felling activities. The dynamic optimal control model is able to improve the rate of carbon absorption through control management on regular felling and plantation process (Kho \& Jepsen 2015; Sanquetta et al. 2015) and simultaneously optimizes the palm oil production.

This paper is organized in 5 sections. A mathematical model is proposed in the second section to address the situation in palm oil plantation. The objective was to maximize oil production while absorbing carbon. Ideally to suit the model with the problem, a simulation process is considered to estimate the best parameters using control parameterization method and Nelder-Mead method. The control problem is then solved and the results are numerically simulated in this section. Finally, the conclusion is given.

\section{THE MODEL}

A model is presented to study carbon absorption in palm oil plantation using a system of ODEs. The model consists of four state variables including standing biomass, growth of biomass, carbon absorption and oil yield. Felling designated as control variables, where the rate of felling is assumed to be controllable. The system equation is defined as,

$$
\begin{aligned}
& \dot{B}(t)=r(t) B(t)\left(1-\frac{B(t)}{k}\right)-F(t) B(t) \\
& \dot{r}(t)=r_{0}-\rho r(t)-\tau F(t) \\
& C(t)=\alpha B(T) \\
& Y(t)=\gamma h B(t)
\end{aligned}
$$

The state variable in (1) describes the dynamics population of palm oil biomass $B(t)$ after considering the growth of biomass minus the felling tree. The growth $r(t)$ is defined by parameter $r_{0}$ minus $r(t)$ and effect of felling. The parameter $r_{0}$ represents the maximum growth rate in the absence of felling activity. The parameter $k$ measure the carrying capacity, $\rho$ is the parameter of natural mortality rate and parameter $\tau$ is the effect of felling on the growth rate.

The carbon absorption of natural plantation depends on the growth of standing biomass (Hritonenko et al. 2008). Thus, the amount of carbon in palm oil can be accumulated by the proportional amount of biomass. The amount of 
yield is reported proportional with the amount of fresh fruit bunches (Banitalebi et al. 2016; Sukiran et al. 2009) indicates in $C(t)$ and $Y(t)$, respectively, in (3) and (4). The $\alpha$ and $\gamma$ are the weighted of carbon absorption and the rate of oil production and $h$ indicates the harvest rate.

\section{SIMULATION}

In order to estimate suitable values for the parameters of the model, a set of data was collected from Malaysian Palm Oil Council (MPOC) and Malaysian Palm Oil Berhad (MPOB). The available data has been collected by sampling from a limited area, and required data was measured in Tonnes per hectare per year except for carbon in Milligrams per hectare. The carbon absorption rate $\alpha$, oil production rate and harvest rate $h$ were collected from previous literatures (Khamiz et al. 2005; Kho \& Jepsen 2015). The rest of the parameters were simulated using control parameterization method (Teo 1991) and Nelder-Mead method (Conn et al. 2009). The control parameterization is to discretize the control space by approximating the control function and Nelder-Mead method is used to find the minimum or maximum of an objective function. The control variable is parameterized as follows,

$$
F(t)=\sum_{i=1}^{m} F_{i} X_{\left[t_{i}, t_{i+1}\right]}(t)
$$

where $X$ is the indicator function such that,

$$
X(t)_{\left[t_{i}, t_{i+1}\right]}= \begin{cases}1, & t \in\left[t_{i}, t_{i+1}\right] \\ 0, & \text { otherwise }\end{cases}
$$

for subinterval $i=1,2,3, \ldots, 30$. The cost function of this control problem is to maximize the performance index as follows,

$$
\max \int_{t_{0}}^{t_{f}}\left(\omega_{1} C^{2}(t)+\omega_{2} Y^{2}(t)\right) d t
$$

The initial and final time are represented by $t_{0}$ and $t f$, respectively. While $\omega_{1}$ and $\omega_{2}$ are weight parameters for carbon absorption and oil production. An optimal solution for the control problem is therefore identified by functions $F(t)$ that maximizing (7) and satisfying the following inequality constraints,

$$
\begin{aligned}
& 0<B(t)<70 \\
& 0.1<F(t)<0.9
\end{aligned}
$$

This constraint ensures that the amount of biomass and felling rate remains within some certain bounds. These bounds have been set based on the limitations and characteristics of the case study considered in this paper.

\section{RESULTS AND DISCUSSION}

Current observation, yield of oil and carbon absorption are depends on the growth of standing biomass. Figure 1 shows the graph of the optimal control of felling when time is varying up to 100 years. This result shows that, at the initial stage when, the young palm oil trees have just been planted, the felling rate is at the lowest value until they are about 20 years old. After that, a maintenance stage is started where the felling rate has a little fluctuation.

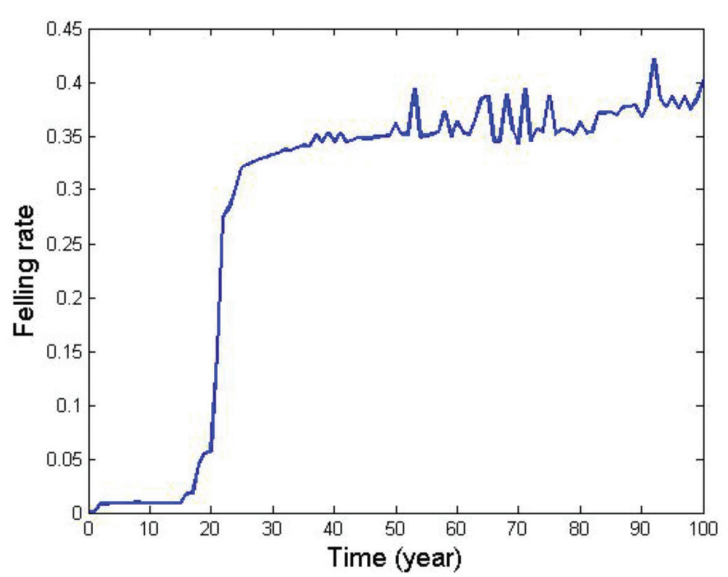

FIGURE 1. The optimal control of felling rate

After control is applied to the system as described in (1) and (2), the optimal state variables are achieved and illustrated in Figures 2 and 3. From the graph, it is clear that the amount of biomass increases with controlled felling rate. However, if no control is applied, the state of biomass is maintain at the lower level, and therefore, the maximum oil yield is hard to be achieved. In addition, based on (3) and (4), the amounts of oil yield and carbon sequestration are proportional to the amount of biomass. This implies that, the amounts oil yield and carbon apportion follows the same as biomass with different scales.



FIGURE 2. Biomass of palm oil plantation in 100 years with and without control on felling 


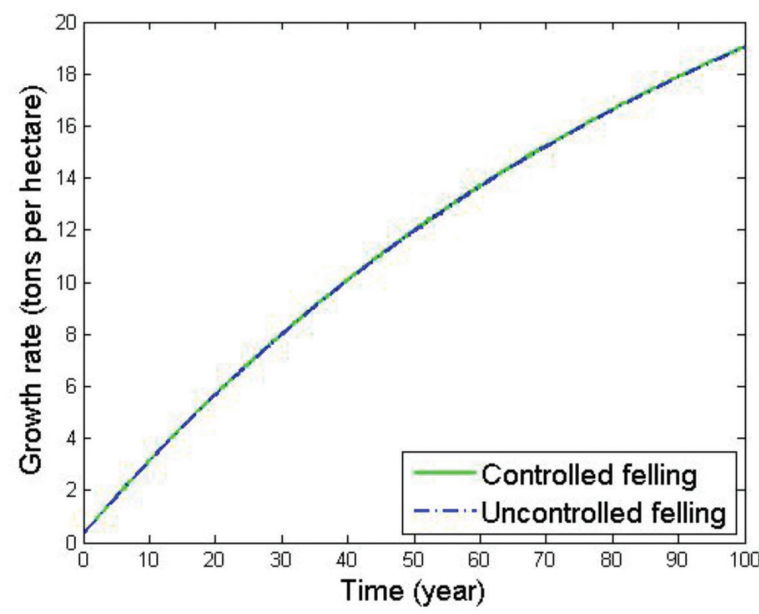

FIGURE 3. The growth rate with and without control on felling

The growth curve is shown in Figure 3. In this figure, carves related to controlled and uncontrolled felling are coincided which suggests that the growth dynamic is not depend on the felling. The standing biomass matured between the age of 15 and 20 years and stagnant hereafter. The fluctuation of yield is associated with felling activity, distruption of Geoderma, Termites and natural weather environment (Sharma 2013). However, this paper ignored these problems and focused on maximizing carbon absorption while producing oil.

\section{CONCLUSION}

This paper presents an optimal control model of palm oil plantation in terms of carbon sequestration and oil production while considering felling rate as the control variable. The parameters of the model were estimated using real data and the resulting control problem was solved. The result of this study can be helpful on palm oil plantation management by regulating the felling rate to achieve not only the maximum oil production but also the maximum carbon absorption.

\section{REFERENCES}

Aholoukpè, H., Dubos, B., Flori, A., Deleporte, P., Amadji, G., Chotte, J.L. \& Blavet, D. 2013. Estimating aboveground biomass of oil palm: Allometric equations for estimating frond biomass. Forest Ecology and Management 292: 122129.

Al-Amin, A.Q., Rajah, R. \& Chenayah, S. 2015. Prioritizing climate change mitigation: An assessment using Malaysia to reduce carbon emissions in future. Environmental Science \& Policy 50: 24-33.

Assmuth, A. \& Tahvonen, O. 2015. Continuous cover forestry vs clearcuts with optimal carbon storage. University of Helsinki. pp. 1-36.

Backeus, S., Wikstrom, P. \& Lamas, T. 2006. Modeling carbon sequestration and timber production in a regional case study. Silva Fennica 40(4): 615-629.

Banitalebi, A., Mohd Ismail, Abd Aziz., Zainal, Abdul Aziz \& Noryanti Nasir. 2016. Modelling and optimization for palm oil plantation management. Advances in Industrial and Applied Mathematics: Proceedings of 23rd Malaysian National Symposium of Mathematical Sciences (SKSM23) 1750: 030046.

Basiron, Y. 2007. Palm oil production through sustainable plantations. European Journal of Lipid Science and Technology 109: 289-295.

Conn, A.R., Scheinberg, K. \&Vicente, L.N. 2009. Introduction to Derivative-Free Optimization Book. 1: 277. doi:10.1137/1.9780898718768.

Corley, R.H.V. \& Tinker, P.B. 2003. The Palm Oil. Oxford: Blackwell Science Ltd

Corley, R.H.V., Hardon, J.J., Tang, Y. \& Tan, G.Y. 1971. Analysis of growth of the oil palm (Elaeis Guineensis Jacq.) I. estimation of growth parameters and application in breeding. Euphytica 20: 307-315.

Gaoue, O.G., Jiang, J., Ding, W., Agusto, F.B. \& Lenhart, S. 2016. Optimal harvesting strategies for timber and non-timber forest products in tropical ecosystems. Theoretical Ecology 9(3): 287-297.

Germer, J. \& Sauerborn, J. 2008. Estimation of the impact of oil palm plantation establishment on greenhouse gas balance. Environment, Development and Sustainability 10(6): 697716.

Goetz, R., Hritonenko, N., Xabadia, A. \& Yatsenko, Y. 2007. Using the escalator boxcar train to determine the optimal management of a size-distributed forest when carbon sequestration is taken. Large-Scale Scientific Computing 4818: 334-341.

Hritonenko, N., Yatsenko, Y., Renan-Ulrich, G. \& Xabadia, A. 2008. Maximum principle for a size-structured model of forest and carbon sequestration management. Applied Mathematics Letters 21(10): 1090-1094.

Jiao, Y.Y., Ren, H.E. \& Dong, B.Z. 2011. Optimal estimation of forest carbon sequestration based on eddy correlation method. Advances in Computer Science, Intelligent System and Environment 2(105): 421-426.

Jones, D.A. \& O'Hara, K.L. 2012. Carbon density in managed coast redwood stands: Implications for forest carbon estimation. Forestry 85(1): 99-110.

Kato, N. 2008. Optimal harvesting for nonlinear size-structured population dynamics. Journal of Mathematical Analysis and Applications 342(2): 1388-1398.

Khamiz, A., Ismail, Z. \& Muhammad, A.T. 2005. Nonlinear growth models for modeling oil palm yield growth. Journal of Mathematics and Statistics 1(3): 225-233.

Kho, L.K. \& Jepsen, M.R. 2015. Carbon stock of oil palm plantations and tropical forests in Malaysia: A review. Singapore Journal of Tropical Geography 36: 249-266.

Kongsager, R., Napier, J. \& Mertz, O. 2013. The carbon sequestration potential of tree crop plantations. Mitigation and Adaptation Strategies for Global Change 18(8): 11971213.

Kula, E. \& Gunalay, Y. 2012. Carbon sequestration, optimum forest rotation and their environmental impact. Environmental Impact Assessment Review 37(11): 18-22.

Mekhilef, S., Siga, S. \& Saidur, R. 2011. A review on palm oil biodiesel as a source of renewable fuel. Renewable and Sustainable Energy Reviews 15(4): 1937-1949.

Patthanaissaranukool, W., Polprasert, C. \& Englande, A.J. 2013. Potential reduction of carbon emissions from crude palm oil production based on energy and carbon balances. Applied Energy 102: 710-717. 
Pei, W., Ng, Q., Loong, H., Yuen, F., Kamal, M., Heng, J. \& Lim, E. 2012. Waste-to-wealth: Green potential from palm biomass in Malaysia. Journal of Cleaner Production 34: 57-65.

Pulhina, F.B., Lascob, R.D. \& Urquiolab, J.P. 2014. Carbon sequestration potential of oil palm in Bohol, Philippines. Ecosystems \& Development Journal 4: 14-19.

Sanquetta, C.R., Pélliconetto, S., Paula, A., Corte, D., Lourenço, A., Behling, Ale., Niroh, M. \& Sanquetta, I. 2015. Quantifying biomass and carbon stocks in oil palm (Elaeis guineensis Jacq.) in Northeastern Brazil. African Journal of Agricultural Research 10(43): 4067-4075.

Sharma, M. 2013. Sustainability in the cultivation of oil palmissues \& prospects for the industry. Journal of Oil Palm \& The Environment An Official Publication of the Malaysian Palm Oil Council (MPOC) 4: 47-68.

Sohngen, B., Golub, A. \& Hertel, T.W. 2009. The role of forestry in carbon sequestration in general equilibrium models. Economic Analysis of Land Use in Global Climate Change Policy 49: 279-303.

Sohngen, B. \& Mendelsohn, R. 2003. An optimal control model of forest carbon sequestration. American Journal of Agricultural Economics 85(2): 448-457.

Somarriba, E., Cerda, R., Orozco, L., Cifuentes, M., Dávila, H., Espin, T., Mavisoy, H., Ávilaa, G., Alvaradoa, E., Povedaa, V., Astorgaa, C., Saya, E. \& Deheuvelsb, O. 2013. Carbon stocks and cocoa yields in agroforestry systems of Central America. Agriculture, Ecosystems \& Environment 173: 46-57.

Sukiran, M.A., Kartini, N.O.R., Bakar, A.B.U. \& Chow, M.E.E.C. 2009. Optimization of pyrolysis of oil palm empty fruit bunches optimization of pyrolysis of oil palm empty fruit bunches. American Journal of Applied Sciences 21(6): 653-658.

Syahrinudin. 2005. The potential of oil palm and forest plantations for carbon sequestration on degraded land in Indonesia. Ecology and Development Series. Goettingen: Cuvillier Verlag.

Teo, K.L. 1991. A unified computational approach to optimal control problems. Proceedings of the First World Congress on World Congress of Nonlinear Analysts, Volume III. New York: Longman Scientific \& Technical.
Wicke, B., Sikkema, R., Dornburg, V. \& Faaij, A. 2011. Exploring land use changes and the role of palm oil production in Indonesia and Malaysia. Land Use Policy 28(1): 193-206.

Xabadia, A. \& Goetz, R.U. 2010. The optimal selective logging regime and the faustmann formula. Journal of Forest Economics 16(1): 63-82.

Noryanti Nasir*, Mohd Ismail Abd Aziz \& Akbar Banitalebi Department of Mathematical Sciences

Faculty of Sciences

Universiti Teknologi Malaysia

81310 UTM Skudai, Johor Bahru, Johor Darul Takzim

Malaysia

Noryanti Nasir*

Faculty of Computer and Mathematical Sciences

Universiti Teknologi MARA

Kampus Seremban

Persiaran Seremban Tiga/1, Seremban 3

70300 Seremban, Negeri Sembilan Darul Khusus Malaysia

Mohd Ismail Abd Aziz \& Akbar Banitalebi

UTM Center for Industrial and Applied Mathematics

Universiti Teknologi Malaysia

81310 UTM, Skudai, Johor Bahru, Johor Darul Takzim Malaysia

*Corresponding author; email: noryanti4@live.utm.my

Received: 7 January 2017

Accepted: 28 September 2017 